\title{
A Sorting Strategy for Alpha Based on ROE Linked with Global Financial Market
}

\author{
Shenkai $\mathrm{Wu}^{1, *}$ \\ ${ }^{1}$ Graduate School of Arts and Sciences, Columbia University in the City of New York, 10027, New York, United States \\ of America \\ ${ }^{*}$ Corresponding author. Email: shenkai.wu@columbia.edu
}

\begin{abstract}
Finding sorting variables for alpha is crucial in investing stocks. The alpha, also referred to as abnormal return, measures the investment strategy's ability to beat the market. It is the part of portfolio return that the existing model cannot explain. Return on equity (ROE) is one of the key factors to evaluate the performance of a corporation. Generally, higher ROE indicates the better profitability of the corporation. In this paper, the Carhart four-factor model is used to simulate alpha, and ROE is applied as a sorting variable. After analyzing quarterly corporate data from 1991 to 2020 , this paper proposes a long-term investment strategy of buying stocks with $10 \%$ lowest ROE and selling stocks with $10 \%$ highest ROE. This strategy brings $1.477 \%$ abnormal return annually, which may provide some suggestions for investors.
\end{abstract}

Keywords: ROE, Carhart four-factor, alpha

\section{INTRODUCTION}

Return on equity (abbreviated as "ROE" below) is a financial ratio used to evaluate a company's profitability. It is a measure of the company's profitability management. If ROE is too low, the company may not be suitable for long-term investment. If ROE is too high, many new companies may enter this industry and decrease this ratio since the market is efficient. Generally, an enterprise performs well with ROE above $20 \%$, while an enterprise performs poorly with ROE below $15 \%$.

$\mathrm{ROE}$ is one of the rigid indicators of listed companies' refinancing and stock issuing qualifications. It is also an important indicator that best reflects the profitability of listed companies and is closely related to optimizing company benefits. ROE can measure the efficiency of the company's use of the capital invested by shareholders and make up for the deficiency of PE.

Therefore, ROE may be a suitable sorting variable to find alpha and generate an investment strategy. It may provide some information for longing or shorting stocks.

This paper is interested in whether an empirical long/short investment strategy exists, adopting the methodologies some of these papers have constructed. Based on the Carhart four factors model, the ordinary least square (OLS) model will be applied to find the strategy's alpha.

\section{LITERATURE REVIEW}

To avoid involuntary delisting, an enterprise may have an incentive to manipulate its profit or financial ratio. $\mathrm{Lu}$ found evidence of listed companies maintaining return on equity (ROE) in the range slightly higher than $0,6 \%$, and $10 \%$ through earnings management to avoid losses or obtain rights issues. Some companies manipulate net profit and manipulate net assets to coin a better financial situation [1]. Zhou et al. got enough evidence that the company chairman also greatly affects ROE [2]. Therefore, ROE is always regarded as one of the most important indicators to evaluate a company's performance and whether it can be invested.

According to Kamar, ROE has a significant effect on the stock price in the cement industry [3]. He suggested that the investors in implementing the investment consider financial factors and pay attention to other factors that are not raised in this study, such as politics, economic, and other to the investment decision, which can benefit the investors. Therefore, the impact of ROE on the long-short stock strategy can be further explored for investors to decide when and how to invest in stocks. 
$\mathrm{Fu}$ showed that the level of return on net assets of monopolistic industries excessively depends on the sales profit rate [4]. The reason is that the price regulation of monopoly industries is not complete enough. The customization of prices is subjective and arbitrary, which allows companies to increase their profits by increasing costs. These two factors interactively bring to a lower potential ROE in the future. Tu concluded that the return on net assets of listed companies on the GEM is positively correlated with the scale of PE financing and the impact time of $\mathrm{PE}$ and has no significant relationship with other indicators of the company [5].

There is obviously a large difference in stock returns during high versus low inflation [6]. Using econometric models, Arshad discovered that ROE is predictable and has a positive correlation with a stock return based on the data of the Shanghai Stock Exchange [7]. This provides an intuition when constructing the model later. According to an ROE target, banks are especially resistant to post-financial crisis regulation after increasing capital [8].

Brav et al. thought the stock returns following equity issues reflect a more pervasive return pattern in the broader set of publicly traded companies. Many of the long-run stock return anomalies found in the finance literature are manifestations of the same return pattern [9]. The Alpha strategy attaches great importance to the absolute return obtained from hedging system risks in the stock investment market. It is a neutral investment method. The specific procedures include selecting assets, optimizing assets, establishing a specific combination method, and making regular adjustments [10]. Therefore, the alpha strategy will be applied in this paper to find a tool subsiding investors' decisions.

\section{DATA}

\subsection{Source}

The ROE data are acquired from CRSP/Compustat Merged Database, while Carhart's four factors are acquired from WRDS, imported from Kenneth French's website at Dartmouth. 782,866 observations are collected, including 20,370 companies. ROE data is quarterly, and the Carhart factor is monthly data. The period is from January 1991 to December 2020, 30 years in total.

\subsection{Cleaning, Manipulating and Merge}

ROE ratio is defined as:

$$
R O E=\frac{n e t \text { income }}{\text { total asset }- \text { total liability }} \times 100 \%
$$

Most of the firms do not have the related financial report data in the early years. One reason is that WRDS does not have access to these data, and another is that the firms were not set up in that year. Therefore, the firms with years having omitted value are deleted. Omit values in stock price are deleted, for they will be used to calculate quarterly returns.

Then data from two sets should be merged for further research. Quarterly return is calculated from a stock price change. Since in some quarters there is no information, months between two consecutive prices are also different. Therefore, the price differences should be divided by the interval length between them. ROE ratio is manually calculated by applying equation 1 above.

\subsection{Ranking}

ROE ratio is ranked and filtered the highest $10 \%$ and lowest $10 \%$. Firms with the highest $10 \%$ ROE are labeled as " $\mathrm{H}$ ", which means high; firms with the lowest $10 \%$ ROE are labeled as "L", which means low. Those data not included are labeled as "N" and deleted.

\section{METHODOLOGY}

The basic model is Carhart's four-factor model:

$$
\begin{aligned}
& E\left(R_{i}\right)-R_{f}=\alpha+\beta_{1} E\left(R_{m}-R_{f}\right)+\beta_{2} E(S M B)+ \\
& \beta_{3} E(H M L)+\beta_{4} E(U M D)
\end{aligned}
$$

For $E\left(R_{i}\right)-R_{f}$ is the excess return of a portfolio based on risk-free return, $E\left(R_{m}-R_{f}\right)$ is the excess return of market-based on risk-free return, $E(S M B)$ is the expectation of return on small capitalization firms minus big capitalization firms, $E(H M L)$ is the expectation of return on high book-to-market ratio firms minus low book-to-market ratio firms, $E(U M D)$ is the expectation of momentum, which is a weighted average of high-performing firms minus low-performing firms. $\alpha$ is interpreted as abnormal returns above the return predicted by investment in the 4 passive factors.

In the research, $\alpha$ is what one can achieve following the investing strategy. ROE is referred to as the sorting variable. This paper proposes an investment strategy of buying stocks of the firms with the highest $10 \%$ longterm investment and selling stocks of firms with the lowest $10 \%$ long-term investment. Regression will be done on the factors to find $\alpha$. 


\section{PORTFOLIO ANALYSIS}

Table 1. Example of financial report data

\begin{tabular}{rrrlrrrrr}
\hline GVKEY & fyearq & fqtr & tasset & liabilities & income & price & industry & share \\
\hline 1004 & 2009 & 1 & 1344.465 & 635.881 & 9.59 & 17.01 & 423860 & 38.927 \\
1004 & 2009 & 2 & 1317.706 & 592.929 & 23.438 & 18.66 & 423860 & 38.932 \\
1004 & 2009 & 3 & 1324.752 & 588.177 & 31.779 & 22.68 & 423860 & 39.025 \\
1004 & 2009 & 4 & 1501.042 & 754.692 & 37.552 & 19.7 & 423860 & 39.484 \\
1004 & 2010 & 1 & 1532.733 & 773.074 & 13.784 & 15.36 & 423860 & 39.663 \\
\hline
\end{tabular}

\subsection{Portfolio Return Comparison}

The ROE data are merged to Carhart's four factors. They are transposed into the high ROE group and low ROE group. A simple test is applied to find the frequency of high ROE firms having higher returns than low ROE firms. It is found that among 119 quarterly observations, there are 64 observations that higher ROE companies performed better and 55 observations that lower ROE companies performed better.

Table 2 Higher side of the return of high/low ROE

\begin{tabular}{|c|c|c|c|c|}
\hline & $\begin{array}{l}\text { Frequenc } \\
\text { y }\end{array}$ & Percent & $\begin{array}{l}\text { Cumulative } \\
\text { percent }\end{array}$ & \\
\hline $\begin{array}{l}\text { High ROE > } \\
\text { Low ROE }\end{array}$ & 64 & 53.78 & & 53.78 \\
\hline $\begin{array}{l}\text { High ROE < } \\
\text { Low ROE }\end{array}$ & 55 & 46.22 & & 100 \\
\hline
\end{tabular}

Another simple test is applied to find the mean of high and low ROE portfolio returns. As shown in the result below (table 3), we notice that given our sample, the high ROE portfolio reveals a mean return of $2.97 \%$, and the low ROE portfolio reveals a mean return of $3.43 \%$. The difference between the two means is around $0.46 \%$, which is a high number that motivates us to investigate further.

Table 3 Mean return of high/low ROE portfolio

\begin{tabular}{rr}
\hline Return of high ROE & Return of low ROE \\
\hline 0.029677 & 0.034331 \\
\hline
\end{tabular}

\subsection{Cumulative Returns for Top and Bottom Portfolios}

A time-series variation of cumulative returns of the portfolios based on the benchmark strategy is plotted in this part. The cumulative return is the product of every period return, which shows how much an investor can get if he invests one dollar in the first quarter. The first valid quarter is the second quarter of 1991, and the last valid quarter is the fourth quarter of 2020, with 119 observations in total.

return of high/low ROE by quarter

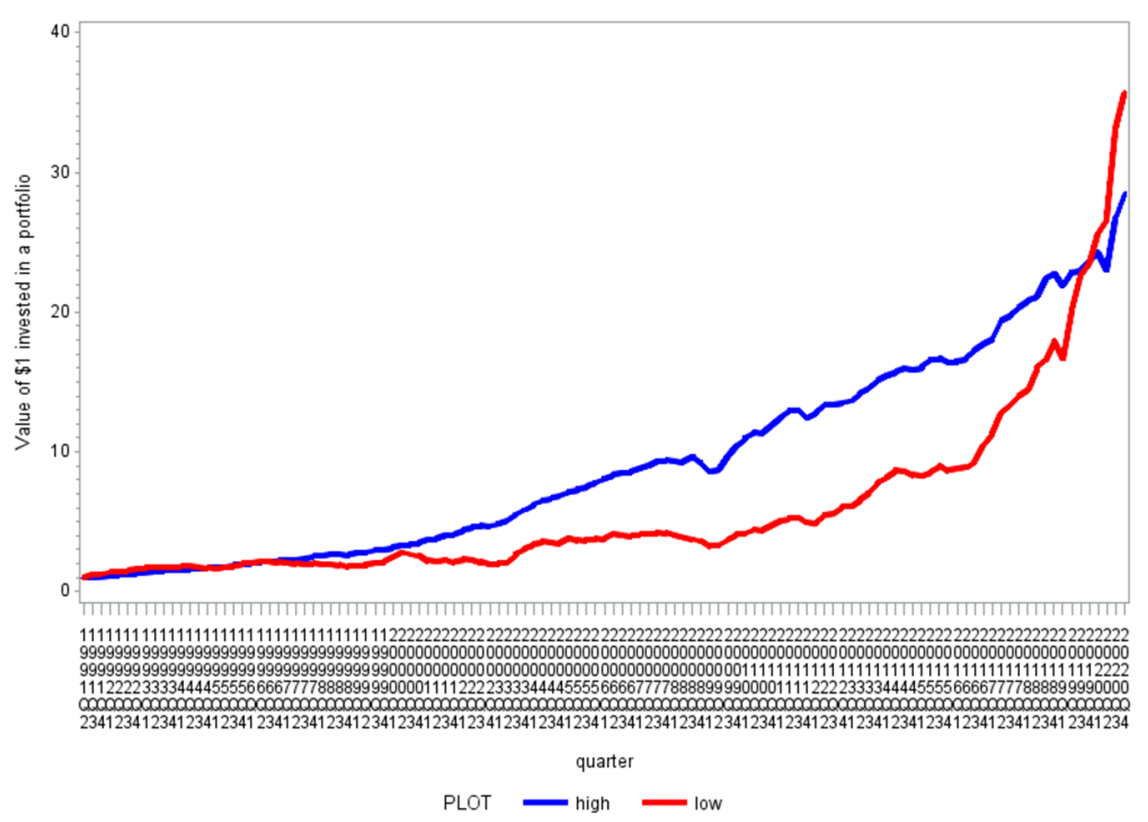

Figure 1 Cumulative returns for top and bottom portfolio with low/high ROE, from 1991 to 2020, under 10\% percentile 
As shown above in figure 1 , in this sample, the cumulative returns of the portfolio with high ROE at first performed worse than the low ROE before 1995 . Then there was a significant increase in the second derivative of return of high ROE. Low ROE around 2020Q1 finally outpaced this trend, maybe influenced by the COVID-19 pandemic.

These results incentivize low ROE firms to have a higher return than high ROE firms. Therefore, in the model regression, the left-hand side, the difference in return, will be referred to as the return of low ROE subtracting return of high ROE.

\subsection{OLS Regression of Top and Bottom 10\% Portfolio}

OLS regression is conducted for the strategy. As shown in table 4 , it is found that the OLS estimates have a significant alpha (at $1 \%$ significance level) of positive value $(0.01477)$ with a t-statistics of 2.83 and a p-value of 0.0055 . It implies that our strategy portfolio with buying firms with lower ROE ratios and selling higher ones can generate positive abnormal returns at a $1 \%$ significance level.

Besides, regarding the Carhart four-factor model as the basic model, it is noticed that in the estimation, the excess return on the market has a positive coefficient with a p-value of 0.2261 , which means it is not significant. The high minus low return (HML) and the momentum factor (UMD) are significant at $1 \%$.

Furthermore, it is found that the coefficient of HML, the difference between the excess return on a portfolio of high-book-to-market stocks and that of low-book-tomarket stocks, is negative and significant. It can be explained as our strategy of choosing firms with lower ROE will have a higher return; thus, it is negatively correlated with the book-to-market rate. Intuitively, low book-to-market stocks tend to be regarded as high growth potential stock rather than value stock, where growth stock often correlates with firms that do not have scale effect and high ROE yet.

\subsection{Robustness Check}

To further confirm the simple OLS result, non-linear OLS regression is conducted with the White correction to fit Carhart Four-Factor Model. The result is shown in table 5, and it shows the same significant alpha as the previous OLS regression result. There is a significant alpha (at the $1 \%$ significance level) of positive value (0.01477) with a t-statistics of 2.57 and a p-value of 0.0114. It is consistent with the preceding conclusion and so that the strategy portfolio can generate the positive

Table 4. OLS regression results based on Benchmark strategy

\begin{tabular}{|c|c|c|c|c|}
\hline Number of Observations & 119 & & R-Square & 0.2384 \\
\hline Root MSE & 0.05059 & & Adj R-Sq & 0.2116 \\
\hline Dependent Mean & 0.00465 & & Coeff Var & 1087.03414 \\
\hline Variable & Parameter estimate & Standard error & t statistic & P-value \\
\hline Intercept & 0.01477 & 0.00522 & 2.83 & $0.0055^{\star * *}$ \\
\hline$R_{m}-R_{f}$ & 0.14408 & 0.11838 & 1.22 & 0.2261 \\
\hline$S M B$ & -0.20963 & 0.16044 & -1.31 & 0.194 \\
\hline$H M L$ & -0.75394 & 0.16858 & -4.47 & $<.0001^{\star \star *}$ \\
\hline$U M D$ & -0.54468 & 0.12943 & -4.21 & $<.0001^{\star \star \star}$ \\
\hline
\end{tabular}

(Note: $* * *$ denotes for $1 \%$ level significant)

$\begin{aligned} \text { Ret }_{d} \text { iff }= & 0.01477+0.14408 E\left(R_{m}-R_{f}\right)-0.20963 E(S M B)-0.75394 E(H M L)-0.54468 E(U M D) \\ & (0.00522)(0.11838)\end{aligned}$ 
Table 5. Non-linear OLS regression results based on Benchmark strategy

\begin{tabular}{|c|c|c|c|c|}
\hline Number of Observations & 119 & & R-Square & 0.2384 \\
\hline Root MSE & 0.05059 & & Adj R-Sq & 0.2116 \\
\hline Variable & Parameter estimate & Standard error & t statistic & P-value \\
\hline Intercept & 0.014766 & 0.00574 & 2.57 & $0.0114^{\star \star \star *}$ \\
\hline$R_{m}-R_{f}$ & 0.144085 & 0.1251 & 1.15 & 0.2519 \\
\hline$S M B$ & -0.20963 & 0.1567 & -1.34 & 0.1837 \\
\hline$H M L$ & -0.75394 & 0.1974 & -3.82 & $0.0002^{* * *}$ \\
\hline$U M D$ & -0.54468 & 0.1474 & -3.69 & $0.0003^{* * *}$ \\
\hline
\end{tabular}

(Note: $* * *$ denotes for $1 \%$ level significant)

Abnormal returns at a $1 \%$ significance level.

\section{CONCLUSION}

In this paper, the Carhart four-factor model is used as the basic model, and the return-on-equity ratio is used as the sorting variable to find the significant alpha, interpreted as abnormal returns. The strategy proposes to buy firms whose ROE ratio is at the bottom fraction of our samples and sell firms whose ROE ratio is at the top fraction.

In order to check if the strategy works, research data is obtained from CRSP and merged by fiscal year and quarter. The Benchmark fraction is chosen as $10 \%$ at the top and $10 \%$ at the bottom. The result gives us an alpha of $1.477 \%$ at a $1 \%$ significance level. Moreover, a robustness check is conducted with non-linear OLS regression with white correction under Four-Factor Model, which also provides an alpha at a $1 \%$ significance level. Therefore, this strategy withstands a robustness check.

In future research, further improvements can be made to illustrate the phenomenon discovered in this paper. Return of different ROE companies varies across years, and there may be different reasons for this variation. It remains unknown whether there is a consistent explanation for the two cross points in the cumulative return plot. It will be more comprehensive if research explores the underlying factors influencing different ROE companies' returns.

\section{REFERENCES}

[1] Lu, Y. Viewing the earnings management behaviour of China's listed companies from the distribution of ROE and ROA. Yunnan, China: Inquiry into Economics Issues, 2002(03), 63-69

[2] Zhou, L., Zhang, L., Wang, H. The relationship of chairman's overseas education background and company performance and the medicating role of listed period. Henan, China: Economic Survey, 2015, 32(06), 149-154.
[3] Kamar, K. Analysis of the effect of return on equity (ROE) and debt to equity ratio (DER) on stock price on cement industry listed in Indonesia stock exchange (IDX) in the year of 2011-2015. IOSR Journal of Business and Management. 2017, 19(05), 66-76.

[4] Fu, W. Analysis of the ROE determinants of the listed corporations in China: industry comparison. Zhejiang Gongshang University. 2015

[5] Tu, F. Private equity investment and company's return on net assets - empirical analysis based on listed companies on the growth enterprise market. Reform and Opening. 2015(24), 37-38.

[6] Reilly, F. The impact of inflation on ROE, growth and stock prices. Financial Services Review. 1997(6), 1-17.

[7] Arshad, M. Forecasted E/P Ratio and ROE: Shanghai Stock Exchange (SSE), China. SAGE Open. 2021

[8] Pennacchi, G., Santos, J. Why do banks target ROE. Journal of Financial Stability. 2021(54)

[9] Brav, A., Geczy, C., Gompers, P. Is the abnormal return following equity issuances anomalous. Journal of Financial Economics. 2000(56), 209-249

[10] Yang, Y. Quantitative investment research based on alpha strategy. China Market. 2015(25), 83-84 